\title{
The effect of milk allowance on behavior and weight gains in dairy calves
}

\author{
K. Rosenberger, ${ }^{1}$ J. H. C. Costa, H. W. Neave, M. A. G. von Keyserlingk, and D. M. Weary ${ }^{2}$ \\ Animal Welfare Program, Faculty of Land and Food Systems, University of British Columbia, Vancouver, V6T 1Z4, Canada
}

\begin{abstract}
The objective of this study was to investigate how milk allowance affects body weight gains and behavior before, during, and after weaning in dairy calves. Fiftysix Holstein calves were randomly assigned at $1 \mathrm{wk}$ of age to 1 of 4 feeding treatments of whole pasteurized milk: $6,8,10$, or $12 \mathrm{~L} / \mathrm{d}$. Milk allowance was reduced by $50 \%$ at $\mathrm{d} 42$, and then reduced by $20 \%$ per day starting at $\mathrm{d} 50$, so that calves were completely weaned at $\mathrm{d} 55$. Calves were provided ad libitum access to calf starter and hay. Body weight was measured weekly from 2 to 10 wk of age. Milk intake increased with milk allowance as intended, although actual intakes were lower than the treatment allowance (e.g., averaging $5.66 \pm 0.19 \mathrm{~L}$ on the 6 - $\mathrm{L}$ treatment and $9.41 \pm 0.21 \mathrm{~L}$ on the $12-\mathrm{L}$ treatment before weaning). Intake of )calf starter was higher for calves that were fed less milk before weaning (averaging $0.25 \pm 0.03 \mathrm{~kg} / \mathrm{d}$ and $0.05 \pm 0.03 \mathrm{~kg} / \mathrm{d}$ on the 6 - $\mathrm{L}$ and $12-\mathrm{L}$ treatments, respectively) and also during the weaning period (averaging $1.15 \pm 0.13 \mathrm{~kg} / \mathrm{d}$ and $0.54 \pm 0.14 \mathrm{~kg} / \mathrm{d}$ on these same treatments), but we observed no effect after weaning. Time spent at the hay feeder did not differ with treatment. Average daily gain was higher for calves that were fed more milk, increasing from $0.77 \pm 0.04 \mathrm{~kg} / \mathrm{d}$ with the 6 -L treatment to $0.90 \pm 0.03 \mathrm{~kg} / \mathrm{d}$ with the 12 -L treatment. Before weaning, calves fed less milk engaged in more unrewarded visits to the milk feeder, averaging $11.1 \pm 0.73$ visits/d with the 6 - $\mathrm{L}$ treatment and $0.4 \pm 0.78$ visits/d with the 12-L treatment. During weaning, calves fed less milk still had more unrewarded visits to the milk feeder than calves fed more milk $(19.7 \pm 1.64$ visits $/ \mathrm{d}$ with the 6 - $\mathrm{L}$ treatment versus $10.1 \pm 1.74$ visits/d with the 12-L treatment), but treatments did not differ after weaning. We conclude that higher milk allowances re-
\end{abstract}

Received March 21, 2016.

Accepted September 9, 2016.

${ }^{1}$ Present address: Department of Farm Animals and Veterinary Public Health, Institute of Animal Husbandry and Welfare, University of Veterinary Medicine, Veterinärplatz 1, 1210, Vienna, Austria.

${ }^{2}$ Corresponding author: danweary@mail.ubc.ca sult in weight gain advantages before weaning that can persist beyond weaning, and that the high number of unrewarded visits to the milk feeder by calves that were fed less milk are indicative of persistent hunger.

Key words: neonatal growth, calf nutrition, automated feeding systems, feed efficiency

\section{INTRODUCTION}

Dairy calves are frequently fed a restricted milk allowance of approximately $10 \%$ of their BW (approximately 4 to 6 L of milk/d; Vasseur et al., 2012; Hötzel et al., 2014; Staněk et al., 2014). A recent survey indicated that $53 \%$ of farms in the United States provide dairy heifer calves with just 4 to $5 \mathrm{~L} / \mathrm{d}$ (USDA, 2016). Calves fed lower milk rations may be more likely to experience the poor-welfare effects of prolonged hunger. For calves fed using automated feeding systems, a high number of unrewarded visits to the milk feeder has been associated with a high motivation to obtain milk (de Passillé et al., 2011), and this measure has been suggested as a method for assessing hunger levels in milk-fed calves (de Paula Vieira et al., 2008). Calves fed low milk rations (in this case, approximately $10 \%$ of the calf's birth weight or 4 to $5 \mathrm{~L}$ of milk per day) show increased behavioral signs of hunger, including a higher number of vocalizations at $5 \mathrm{wk}$ of age (Thomas et al., 2001) and unrewarded visits to the milk feeder (Jensen and Holm, 2003, 3 to 9 wk of age; de Paula Vieira et al., 2008, 1 to 2 wk of age). They also grow more slowly before weaning than calves fed more milk (Appleby et al., 2001; Diaz et al., 2001; Khan et al., 2011a; Kiezebrink et al., 2015).

Calves fed lower milk rations may attempt to compensate with increased intake of calf starter, especially after 4 wk of age (Khan et al., 2007, 2016). Increased familiarity with solids before weaning is likely helpful in smoothing the transition from milk to solid feeds at weaning, so that lower milk rations before weaning may help reduce weaning stress and growth check at weaning. Several studies have reported higher solid intakes in calves fed less milk, leading to improved weight gains around weaning (Huuskonen and Khalili, 2008; Bach et al., 2013). In some cases, this advantage may allow the 
BW of calves fed less milk to catch up with that of calves fed more milk; for example, de Passillé et al. (2011) found that calves fed $12 \mathrm{~L} / \mathrm{d}$ and weaned abruptly lost their BW advantage after weaning. Abrupt weaning of calves fed high volumes of milk also increases the signs of hunger associated with low energy intake (Nielsen et al., 2008).

To ease the transition to a solid diet for calves fed more milk, several techniques can be used to increase starter intake before weaning. For example, gradual weaning methods (including step-down techniques; Khan et al., 2007) and social housing (Costa et al., 2015, 2016; Jensen et al., 2015) can increase solid feed intake before weaning and help maintain BW during and after weaning. The use of these techniques, combined with milk allowances $>15 \%$ of BW, may allow for improved weight gains and calf welfare compared to the standard allowance of $10 \%$ of BW (Khan et al., 2011a).

Previous studies have mostly compared low and high milk allowances, but to our knowledge, few studies have examined a range of allowances. Kristensen et al. (2007) studied the effect of 4 different milk allowances $(3.1,4.8,6.6$, and $8.3 \mathrm{~L} / \mathrm{d})$ on ruminal development and environment and on starter intake, but in this study, calves were housed individually. Yavuz et al. (2015) compared the effects of 4-, 6-, and 8-L milk allowances on calf growth, health, and development, but did not group-house calves or provide early access to forage (only at d 35 of age). As well, neither of these studies included allowances $>9 \mathrm{~L}$ of milk, but such higher allowances are more similar to intakes achieved by calves provided ad libitum access to milk. Also, these studies did not record unrewarded visits to the milk feeder. These factors are important for identifying the effects of higher milk allowances and help provide a scientific basis for recommended milk allowances on farms using group housing. The aim of this study was to determine the effect of milk allowance across a range of values (6, 8,10 , and $12 \mathrm{~L}$ of milk/d) on feed intake, the number of unrewarded visits to the milk feeder, and BW gains. We predicted that calves fed increased amounts of milk would have higher ADG and lower solid feed intakes before weaning. We also predicted that during weaning, solid feed intakes would increase rapidly for all calves, so that by the time calves were fully weaned, solid feed intakes would not differ. Finally, we predicted that calves fed less milk would experience more hunger and engage in more unrewarded visits to the milk feeder.

\section{MATERIALS AND METHODS}

The study was conducted from April to October 2015 at the University of British Columbia Dairy Education and Research Centre in Agassiz, BC, Canada. The study was approved under the University of British Columbia Animal Care protocol \#A14-0245.

\section{Housing and Animal Management}

This experiment used 56 Holstein calves (32 females, 24 males) that were separated from the dam within $6 \mathrm{~h}$ of birth, weighed, moved into individual sawdustbedded pens $(1.22 \times 2.44 \mathrm{~m})$, and fed $4 \mathrm{~L}$ of colostrum (with $>50 \mathrm{~g} / \mathrm{L}$ of $\operatorname{IgG}$ ) with the first meal, provided within $6 \mathrm{~h}$ of birth. Blood samples were taken from the jugular vein $24 \mathrm{~h}$ after calves were fed colostrum, and serum protein was measured using a Reichert AR 200 Digital Hand-Held Refractometer (Reichert, Depew, NY). All calves enrolled had serum protein levels $>5.2$ $\mathrm{g} / \mathrm{dL}$.

At $7.5 \pm 1.3 \mathrm{~d}$ of age (nominally d 7 ), calves were moved to sawdust-bedded group pens of 8 calves each $(4.87 \times 7.31 \mathrm{~m})$, with a partially slatted floor. Groups were filled in relation to birth dates, and once group size reached 8, a new group was begun. This process continued until all 7 groups (56 calves) had completed the study.

Calves had access to pasteurized whole milk, fed at $40^{\circ} \mathrm{C}$ using automated feeders (CF 1000 CS Combi; DeLaval Inc., Tumba, Sweden). The milk allowance accrued hourly at a rate of $5 \%$ of the daily value every hour from midnight to $2000 \mathrm{~h}$. The automated milk feeder was set to deliver a minimum amount of $500 \mathrm{~mL}$ of milk per visit, but otherwise calves were allowed to split their accumulated milk allowance in as many visits as they wished. Each pen had 1 milk feeder equipped with 1 teat.

Milk samples were collected once per week and analyzed separately (Pacific Milk Analysis Lab, Chilliwack, BC, Canada). Calf starter (Hi-Pro Medicated; Chilliwack, BC, Canada) was fed ad libitum from the same automated feeder used for milk. The feeder recorded intake and the time and duration of each visit. Farm hay and water were available ad libitum from automatic Insentec feeders that measured time and duration of each visit (RIC; Insentec B.V., Marknesse, the Netherlands). Starter and hay samples were taken weekly and frozen; nutrient analysis was performed at A\&L Canada Laboratories Inc. (London, ON, Canada). Samples for nutrient and DM analysis were oven-dried at $55^{\circ} \mathrm{C}$ for $48 \mathrm{~h}$. Dried samples were ground to pass through a $1-\mathrm{mm}$ screen and for analysis of ADF (AOAC International, 2000, method 973.18); NDF with heat-stable $\alpha$-amylase and sodium sulfite (Van Soest et al., 1991); and CP $(\mathrm{N} \times 6.25 ;$ AOAC International, 2000, method 990.03; Leco FP-528 Nitrogen Analyzer, Leco, St. Joseph, MI). Milk, starter, and hay nutrient analyses are described in Table 1. 
Table 1. Mean $( \pm \mathrm{SD})$ chemical composition of milk, starter, and hay on a DM basis fed to Holstein heifer calves fed $6,8,10$, or $12 \mathrm{~L}$ of milk per day

\begin{tabular}{lccc}
\hline Variable & Milk & Starter & Hay $^{3}$ \\
\hline DM (\%) & $12 \pm 0.46$ & $89.3 \pm 0.6$ & $85.7 \pm 2.8$ \\
CP (\%) & $3.2 \pm 0.29$ & $19.8 \pm 0.5$ & $18.9 \pm 2.1$ \\
Fat (\%) & $3.8 \pm 0.24$ & $6.3 \pm 0.4$ & ND $^{4}$ \\
Lactose (\%) & $3.9 \pm 0.19$ & ND & ND \\
NDF (\%) & ND & $15.4 \pm 0.9$ & $52.8 \pm 2.1$ \\
ADF (\%) & ND & $9.4 \pm 0.8$ & $32.1 \pm 1.6$ \\
Starch (\%) & ND & $37.6 \pm 2.9$ & ND \\
Ash (\%) & ND & $5.8 \pm 0.4$ & ND \\
ME $^{5}($ Mcal $/ \mathrm{kg})$ & $5.8 \pm 0.18$ & $3.0 \pm 0.02$ & $2.3 \pm 0.03$ \\
\hline
\end{tabular}

${ }^{1}$ Pasteurized whole milk storage tank samples $(\mathrm{n}=8)$.

${ }^{2} \mathrm{Hi}-$ Pro Medicated (50 mg/kg of lasalocid sodium; Chilliwack, BC, Canada).

${ }^{3}$ Mixture of farm hay [festulolium: tall fescue (Festuca arundinacea $) \times$ ryegrass (Lolium perenne L.) cross], orchard grass (Dactylis glomerata L.), and ryegrass (Lolium perenne L.).

${ }^{4} \mathrm{ND}=$ not determined.

${ }^{5} \mathrm{ME}=\mathrm{TDN} \times 0.04409 \times 0.82 ;$ calculated according to NRC $(2001)$ equations.

\section{Experimental Design and Treatments}

Calves were randomly assigned to 4 milk-feeding treatments $(6,8,10$, or $12 \mathrm{~L} / \mathrm{d}$ of milk) within each group of 8 calves, with the constraint that each group always contained 2 calves in each treatment. Milk was reduced to $50 \%$ of the allowance at $42 \mathrm{~d}$ of age and then reduced by $20 \%$ per day from d 50 for the last 5 $\mathrm{d}$ until calves were completely weaned at $\mathrm{d} 55$. Calves assigned to the different treatments were similar in sex, BW, 24-h serum total protein, calving ease, and order of enrollment in the group (Table 2).

\section{Data Recording}

Intake of milk and the number of unrewarded visits (in which the calf did not receive milk) were recorded daily until $70 \mathrm{~d}$ of age by the automated milk-feeding system. Daily starter intake was also monitored automatically using the feeding system. Hay intakes were too low to be measured accurately, especially in the first few weeks of life; instead, we monitored the time spent at the hay feeder (again recorded automatically by the hay feeder). Total DMI was calculated by adding the milk and starter DMI. We also calculated the total $\mathrm{ME}$, fat, and $\mathrm{CP}$ intake for the experimental period based on milk and starter intake. We also calculated ADG (kg of BW/d), gain:feed ratio (kg of BW gain/ total DMI), BW gain/ME (kg of BW gain/total Mcal), $\mathrm{BW}$ gain/fat intake ( $\mathrm{kg}$ of $\mathrm{BW}$ gain $/ \mathrm{kg}$ of fat intake), and $\mathrm{BW}$ gain $/ \mathrm{CP}$ intake $(\mathrm{kg}$ of $\mathrm{BW}$ gain $/ \mathrm{kg}$ of $\mathrm{CP}$ intake) for the whole experimental period.

Health checks were performed weekly following the procedure of Costa et al. (2015). Briefly, fecal scores were $1=$ normal feces; $2=$ plaques, but not watery; 3 $=$ watery and body temperature $<39.5^{\circ} \mathrm{C} ; 4=$ watery and body temperature $\geq 39.5^{\circ} \mathrm{C}$. During the experimental period, no calf showed a score of 4 , and no calf was treated for diarrhea. Respiratory health was assessed based on nasal discharge and pathological sounds indicative of pulmonary inflammation. According to these criteria, 2 calves ( 1 from the 12-L group treated once and 1 from the 6 -L group treated 3 times) were classified as ill and treated with an antibiotic (Resflor GOLD; Intervet Inc., Roseland, NJ) according to the farm's standard operating procedure. During the health check, calves were weighed weekly while standing on a portable scale.

\section{Statistical Analysis}

All analyses were performed using SAS (version 9.4; SAS Institute Inc., Cary, NC) using calf as the experimental unit. All variables were screened using the UNIVARIATE procedure in SAS using box, distribution, and probability plots. No outliers were detected, and no transformations were deemed necessary. Calves with a score of 3 or higher for diarrhea, an indication of pulmonary inflammation for 2 or more weeks, or both, were considered sick; this dichotomous variable (sick or not sick) was included in the analysis but was never found to be significant and is not reported below.

To examine the effect of milk allowance, data were analyzed using PROC MIXED in SAS. Milk allowance

Table 2. The distribution of sex, calving difficulty, mean $( \pm \mathrm{SD})$ birth weight, and serum total protein for calves $(\mathrm{n}=56)$ assigned to each milk allowance treatment

\begin{tabular}{lcccc}
\hline & \multicolumn{4}{c}{ Milk allowance $(\mathrm{L} / \mathrm{d})$} \\
\cline { 2 - 5 } Item & 6 & 8 & 10 & 12 \\
\hline Sex (no. female/male) & $8 / 6$ & $8 / 6$ & $8 / 6$ & $8 / 6$ \\
Calving difficulty (no. U/E/M) & $10 / 2 / 2$ & $11 / 3 / 0$ & $14 / 0 / 0$ & $11 / 3 / 0$ \\
Birth weight (kg) & $40.9 \pm 4.3$ & $40.2 \pm 5.7$ & $41.4 \pm 5.6$ & $41.6 \pm 4.8$ \\
Serum total protein (g/dL) & $6.4 \pm 0.8$ & $6.2 \pm 0.5$ & $6.1 \pm 0.6$ & $6.5 \pm 0.6$ \\
\hline
\end{tabular}

${ }^{1} \mathrm{U}=$ unassisted calving, $\mathrm{E}=$ easy calving, $\mathrm{M}=$ malpresentation. 
was used as a continuous variable to test the linear and quadratic effect of the treatment for all the variables; no quadratic effect was significant, so we report only linear effects. We analyzed milk and starter intake, unrewarded visits, time at hay feeder, and ME by period (preweaning, weaning, and postweaning). Measures assessed across the entire experiment included ADG, total ME, total DMI, milk and starter DMI, total CP intake, total fat intake, BW gain/ME, gain:feed ratio (BW gain/DMI), and BW gain/CP intake. For all variables except ADG, the model included the fixed effects of treatment, birth weight, sex, and group order. Group was specified as a random effect. To determine whether BW could explain additional variation in the number of unrewarded visits to the milk feeder, we used a type 1 model specifying BW after treatment in the model above. Results are reported as least squares means and standard errors.

\section{RESULTS}

\section{Milk}

As intended, the actual daily milk intakes increased with milk allowance (Figure 1). In the period before weaning, the average intake was somewhat lower than the daily allowance, even for the lowest treatment (e.g., 5.6 vs. $6 \mathrm{~L} / \mathrm{d}$; Table 3); this difference between the allowance and intake increased with increasing allowances such that at the highest allowance of $12 \mathrm{~L} / \mathrm{d}$ milk intake averaged 9.6 L. During weaning, intakes again varied with treatment as expected and again did not reach the full allowance. Total milk DMI, as expected, also increased with milk allowance (e.g., 21.4 vs. 11.9 $\mathrm{kg}$ of $\mathrm{DM}$ for calves fed 12 and $6 \mathrm{~L} / \mathrm{d}$ respectively; Table 4).

\section{Rewarded and Unrewarded Visits}

Before weaning, the number of rewarded visits to the feeder was higher for calves fed less milk. This pattern reversed during the weaning period, with calves on the higher milk allowances receiving more milk meals. By definition, rewarded visits did not take place after calves were weaned.

Calves in all treatments visited the feeder at times when they were not eligible for milk. Before weaning, unrewarded visits were more frequent for calves fed less milk (especially for calves on the lowest milk allowance). During weaning, the total number of unrewarded visits was higher across all treatments. Again, calves fed less milk engaged in more unrewarded visits, although the effect of treatment was reduced during the weaning period. After weaning, when by definition all visits were a)

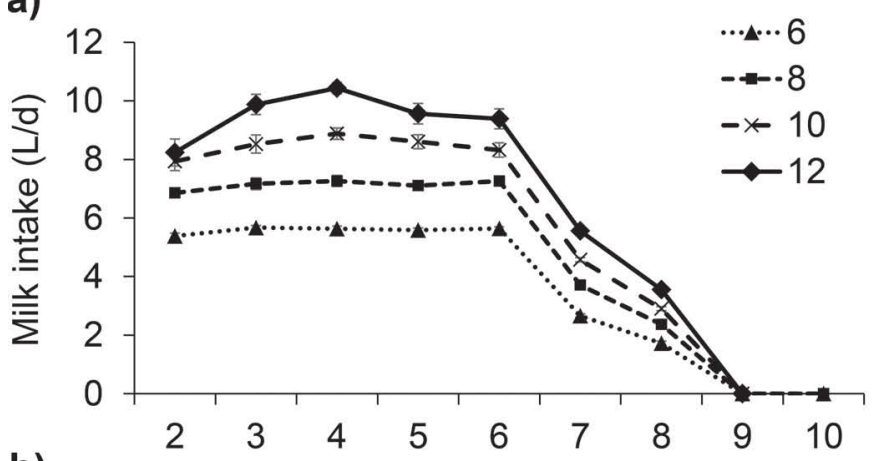

b)
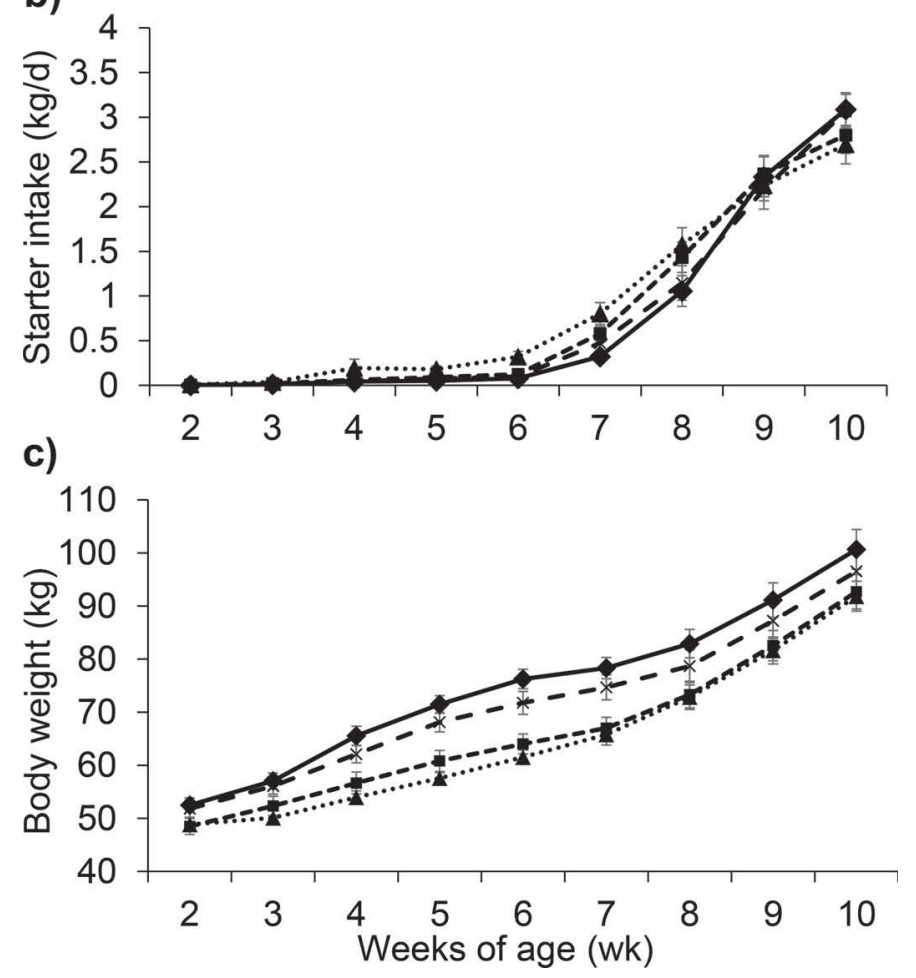

Figure 1. Least squares means $( \pm \mathrm{SE})$ of (a) milk intake, (b) starter intake, and (c) BW for Holstein calves aged 2 to $10 \mathrm{wk}$. Values are shown separately for calves fed $6(\mathrm{n}=14), 8(\mathrm{n}=14), 10(\mathrm{n}=14)$, or $12(\mathrm{n}=14) \mathrm{L}$ of whole milk daily. Calves were offered their full milk allowance from wk 1 to 6 . Milk was reduced to $50 \%$ during wk 7 , and then by $20 \% / d$ so that calves were completely weaned by wk 9 .

unrewarded, calves continued to visit the feeder on average about 5 times/d; this number did not vary with treatment. After accounting for the effect of treatment, BW had no effect on the number of unrewarded visits before, during, or after weaning.

\section{Starter and Hay}

Before weaning, starter intake was higher for calves fed less milk; calves on the lowest milk intake consumed on average $0.25 \mathrm{~kg} / \mathrm{d}$, compared with just $0.05 \mathrm{~kg} / \mathrm{d}$ for 
Table 3. Least squares means of daily milk intake; number of rewarded and unrewarded visits to the milk feeder; starter intake; time at the hay feeder; and ADG for calves $(\mathrm{n}=56)$ fed $6,8,10$, or $12 \mathrm{~L}$ of milk/d

\begin{tabular}{|c|c|c|c|c|c|c|c|}
\hline \multirow[b]{2}{*}{ Item } & \multicolumn{4}{|c|}{ Milk allowance $(\mathrm{L} / \mathrm{d})^{1}$} & \multirow[b]{2}{*}{$\mathrm{SE}$} & \multirow[b]{2}{*}{$F$-value } & \multirow[b]{2}{*}{$P$-value } \\
\hline & 6 & 8 & 10 & 12 & & & \\
\hline \multicolumn{8}{|l|}{ Milk } \\
\hline Preweaning (d 7 to 41 ) & & & & & & $F_{139}$ & \\
\hline Intake $(\mathrm{kg} / \mathrm{d})$ & 5.7 & 7.2 & 8.3 & 9.4 & 0.2 & 188.7 & $<0.001$ \\
\hline Rewarded visits (no./d) & 9.7 & 9.8 & 7.7 & 6.6 & 0.7 & 15.09 & $<0.001$ \\
\hline Unrewarded visits (no./d) & 11.1 & 3.6 & 1.7 & 0.4 & 0.8 & 72.0 & $<0.001$ \\
\hline Weaning (d 42 to 54 ) & & & & & & $F_{1.39}$ & \\
\hline Intake $(\mathrm{kg} / \mathrm{d})$ & 2.4 & 3.3 & 4.0 & 4.9 & 0.1 & $1,676.9$ & $<0.001$ \\
\hline Rewarded visits (no./d) & 4.7 & 6.6 & 6.8 & 7.5 & 0.4 & 38.26 & $<0.001$ \\
\hline Unrewarded visits (no./d) & 19.7 & 16.6 & 11.8 & 10.1 & 1.7 & 23.9 & $<0.001$ \\
\hline Postweaning (d 55 to 68 ) & & & & & & $F_{1.39}$ & \\
\hline Unrewarded visits (no./d) & 5.6 & 5.3 & 5.0 & 4.4 & 0.6 & 1.5 & 0.23 \\
\hline \multicolumn{8}{|l|}{ Starter intake $(\mathrm{kg} / \mathrm{d})$} \\
\hline Preweaning (d 7 to 41 ) & & & & & & $F_{1.39}$ & \\
\hline Starter intake $(\mathrm{kg} / \mathrm{d})$ & 0.3 & 0.1 & 0.1 & 0.0 & 0.0 & 20.6 & $<0.001$ \\
\hline Weaning (d 42 to 54 ) & & & & & & $F_{1.39}$ & \\
\hline Starter intake $(\mathrm{kg} / \mathrm{d})$ & 1.2 & 1.0 & 0.7 & 0.5 & 0.1 & 16.5 & $<0.01$ \\
\hline Postweaning (d 55 to 68 ) & & & & & & $F_{1.39}$ & \\
\hline Starter intake $(\mathrm{kg} / \mathrm{d})$ & 2.7 & 2.8 & 2.9 & 2.9 & 0.2 & 2.4 & 0.13 \\
\hline \multicolumn{8}{|l|}{ Hay } \\
\hline Preweaning (d 7 to 41$)$ & & & & & & $F_{1.31}$ & \\
\hline Time at feeder $(\min / \mathrm{d})$ & 15.5 & 14.7 & 10.4 & 12.7 & 3.1 & 2.0 & 0.16 \\
\hline Weaning (d 42 to 54 ) & & & & & & $F_{1.33}$ & \\
\hline Time at feeder $(\mathrm{min} / \mathrm{d})$ & 27.2 & 27.7 & 21.9 & 29.1 & 3.8 & 0.0 & 0.94 \\
\hline Postweaning (d 55 to 68 ) & & & & & & $F_{1.39}$ & \\
\hline Time at feeder $(\mathrm{min} / \mathrm{d})$ & 27.5 & 30.2 & 30.4 & 27.1 & 2.7 & 0.0 & 0.95 \\
\hline \multicolumn{8}{|l|}{$\mathrm{ADG}$} \\
\hline Preweaning (d 7 to 41 ) & & & & & & $F_{1.39}$ & \\
\hline ADG $(\mathrm{kg} / \mathrm{d})$ & 0.58 & 0.57 & 0.65 & 0.88 & 0.07 & 11.1 & 0.002 \\
\hline Weaning (d 42 to 54 ) & & & & & & $F_{1.39}$ & \\
\hline $\mathrm{ADG}(\mathrm{kg} / \mathrm{d})$ & 0.91 & 0.89 & 0.89 & 0.80 & 0.43 & 0.43 & 0.51 \\
\hline Postweaning (d 55 to 68 ) & & & & & & $F_{1.39}$ & \\
\hline $\mathrm{ADG}(\mathrm{kg} / \mathrm{d})$ & 1.27 & 1.23 & 1.32 & 1.26 & 0.05 & 0.05 & 0.83 \\
\hline
\end{tabular}

${ }^{1}$ All calves were offered their allowance from d 7 to $41,50 \%$ of their allowance per day from d 42 to 49 , and then their allowance was reduced by $20 \% / \mathrm{d}$ for the last $5 \mathrm{~d}$ until calves were completely weaned at $\mathrm{d} 55$.

calves on the 12-L treatment (Table 3). During weaning, intakes increased in all treatments, but were still highest for calves fed lower milk allowances. After weaning, starter intakes averaged almost $3 \mathrm{~kg} / \mathrm{d}$ and did not vary by treatment. Over the entire experimental period, the total starter DMI and the number of visits to the hay

Table 4. Least squares means of ADG; milk DMI; starter DMI; total ${ }^{1}$ ME, CP, and fat intake; and BW gains in relation to these measures, for calves $(\mathrm{n}=56)$ fed $6,8,10$ or $12 \mathrm{~L}$ of milk/d from d 7 to d $68^{2}$

\begin{tabular}{|c|c|c|c|c|c|c|c|}
\hline Item & \multicolumn{4}{|c|}{ Milk allowance $(\mathrm{L} / \mathrm{d})$} & $\mathrm{SE}$ & $F$-value ${ }^{3}$ & $P$-value \\
\hline $\mathrm{ADG}(\mathrm{kg} / \mathrm{d})$ & 0.77 & 0.78 & 0.81 & 0.90 & 0.04 & 6.42 & 0.01 \\
\hline Starter DMI (kg) & 64.0 & 63.7 & 63.4 & 60.3 & 6.7 & 0.44 & 0.50 \\
\hline Total ME (Mcal) & 260.9 & 279.1 & 295.1 & 305.1 & 20.6 & 7.95 & 0.001 \\
\hline Total CP intake $(\mathrm{kg})$ & 17.3 & 18.2 & 19.9 & 19.0 & 1.5 & 2.43 & 0.13 \\
\hline Gain:feed ratio (kg of BW/DMI) & 0.73 & 0.71 & 0.72 & 0.76 & 0.046 & 0.46 & 0.50 \\
\hline $\mathrm{BW}$ gain by $\mathrm{CP}$ intake ( $\mathrm{kg}$ of $\mathrm{BW} / \mathrm{kg}$ of $\mathrm{CP}$ intake) & 3.2 & 3.1 & 3.1 & 3.2 & 0.19 & 0.07 & 0.80 \\
\hline
\end{tabular}

${ }^{1}$ Totals are calculated from intakes of milk and starter only. Calves also consumed forage, but intakes could not be recorded reliably.

${ }^{2}$ All calves were offered their allowance from d 7 to $41,50 \%$ of their allowance per day from d 42 to 49 , and then their allowance was reduced by $20 \% / \mathrm{d}$ for the last $5 \mathrm{~d}$ until calves were completely weaned at $\mathrm{d} 55$.

${ }^{3} \mathrm{df}=1,39$. 
feeder were similar across milk allowance treatments (Table 4).

\section{Growth and Feed Efficiency}

The effect of the milk-feeding treatment on ADG varied by period. As expected, weight gains were affected by treatment before weaning (when most milk was fed); calves fed more milk gained more weight. During and after weaning, we observed no effect of treatment on ADG. The benefits of higher early milk intake persisted so that ADG over the course of the entire experiment was higher for calves fed more milk (Table 4). We observed no effect of treatment on feed efficiency measures (BW gain/ME intake, gain:feed ratio, BW gain/ $\mathrm{CP}$ intake) during the experimental period.

\section{DISCUSSION}

\section{Milk}

As expected, milk intake increased with milk allowance. Calves assigned to the $12-\mathrm{L}$ treatment had an average intake of $>9 \mathrm{~L} / \mathrm{d}$, a value similar to that reported in earlier studies for calves fed ad libitum from teats (Appleby et al., 2001; Jasper and Weary, 2002), but somewhat lower than those reported in other studies (de Passillé and Rushen, 2006; Hepola et al., 2008). A difference between the amount of milk allocated and the amount consumed has been documented in previous research (e.g., Nielsen et al., 2008; Borderas et al., 2009; Sweeney et al., 2010) and may be an issue on commercial farms that use automated milk feeders. This difference was apparent even with the lowest rations, suggesting the gap was not due to a lack of feeding motivation on the part of the calf. Previous research has shown that calves with ad libitum access to milk can consume very large amounts of milk (up to 16 L/d; Borderas et al., 2009; Miller-Cushon et al., 2013).

\section{Rewarded and Unrewarded Visits}

Calves fed less milk visited the milk feeder much more frequently than calves fed more milk. This result is consistent with the idea that these calves were hungry (de Paula Vieira et al., 2008) and supports the results of previous studies (Jensen and Holm, 2003; Jensen, 2006; Nielsen et al., 2008), which showed that calves fed less milk engaged in more unrewarded visits to the milk feeder. Interestingly, some earlier studies reported even higher frequencies of unrewarded visits before weaning, perhaps because they used even lower milk rations (e.g., $4.8 \mathrm{~L} / \mathrm{d}$ ).
Calves fed less milk typically also weigh less, and some have argued that lighter calves may engage in more unrewarded visits because they are more often displaced by their larger group mates at the milk feeder (Hepola, 2003). To test this idea, we included BW in our model, but found that BW did not explain any of the residual variation in the number of unrewarded visits (beyond that explained by the effect of treatment); we conclude that the increased number of unrewarded visits was not due to lower BW in itself.

Unrewarded visits increased during weaning for all treatments, but calves fed more milk still had fewer unrewarded visits. This finding corresponds with previous literature, which showed that higher milk allowance resulted in fewer unrewarded visits during weaning (Jensen, 2006). If a higher number of unrewarded visits is considered indicative of hunger (de Paula Vieira et al., 2008), these results indicate that calves fed lower milk rations experience hunger throughout the preweaning and weaning periods, a finding that should be considered an important welfare concern.

Because calves fed less milk were visiting the milk feeder more frequently, they also had more milk meals (i.e., rewarded visits) during the preweaning period. Naturally, these meals were smaller (at or near the 0.5$\mathrm{L}$ minimum set by the feeder), perhaps leaving calves hungry. Interestingly, the pattern for the rewarded visits was reversed during the weaning period: calves fed the least milk consumed the fewest meals. We speculate that this relationship was due to a ceiling effect. Calves allocated to the 6 - $\mathrm{L}$ treatment could receive a maximum of $3 \mathrm{~L}$ during the weaning period (i.e., a maximum of just 6 meals, close to our recorded mean of 4.7 rewarded visits). In contrast, calves on the $12-\mathrm{L}$ treatment could receive $6 \mathrm{~L}$ during the weaning phase, and thus were still eligible for 12 milk meals (almost double the 7.5 consumed on average). More work is now required to better understand how motivation to consume milk and the constraints imposed by the milk feeder affect rewarded and unrewarded visits.

\section{Starter and Hay}

Before weaning, calves that were fed more milk consumed less starter; this result was consistent with our predictions and common to studies investigating higher milk-feeding levels (Terré et al., 2007; Raeth-Knight et al., 2009; Hill et al., 2010, 2013). Calves fed less milk likely attempted to compensate for the lack of nutrients by consuming more starter. Increased intake of starter before weaning can ease the transition from milk to solid feed and decrease weaning distress (Weary et al., 2008). Thus, feeding higher milk rations requires man- 
agement to increase calf interest in solid food before weaning. One approach used in the present study was to house calves socially. Social housing is known to reduce food neophobia and the latency to eat solid feed in calves (Costa et al., 2014), as well as to increase starter intake before weaning (de Paula Vieira et al., 2012; Costa et al., 2016). Socially housed calves also vocalize less at weaning, suggesting that social buffering can reduce the negative effects of this stressor (de Paula Vieira et al., 2010).

As predicted, and in line with earlier work (Khan et al., 2016), all groups rapidly increased starter intake during and immediately following weaning, such that by $70 \mathrm{~d}$ of age, calves in all treatments were consuming more than $3 \mathrm{~kg} / \mathrm{d}$ of starter. This rapid surge in starter intake at weaning has been reported in earlier studies feeding high volumes of milk (Sweeney et al., 2010; Khan et al., 2011b; Miller-Cushon et al., 2013). After weaning, starter intake was similar across treatments, again consistent with some previous studies (Jasper and Weary, 2002; Khan et al., 2007) but in contrast with others, where calves fed high milk rations were reported to require several weeks before their intake of solid feed matched those of calves fed less milk (Huuskonen and Khalili, 2008; de Passillé et al., 2011). These differences among studies may be due to how calves were managed around weaning. In the present study, we provided social housing, access to forage, and weaned calves using a step-down procedure, where milk allowance was initially reduced at $42 \mathrm{~d}$ and then again at weaning (d 50-54); all of these factors may have increased starter intake before and during weaning and may help to explain the lack of difference in total starter intake throughout the experimental period.

\section{Growth and Feed Efficiency}

Weight gains in the present study were higher in calves fed more milk. Previous research has consistently shown that providing higher amounts of milk improves preweaning weight gains (e.g., Diaz et al., 2001; Cowles et al., 2006) and may have positive effects on production and reproduction later in life (Davis Rincker et al., 2011; Soberon et al., 2012; Soberon and Van Amburgh, 2013; Dance et al., 2015). In our study, we found no differences in feed efficiency (gain:feed ratio, $\mathrm{kg}$ of $\mathrm{BW}$ gain/Mcal of $\mathrm{ME}$ intake, $\mathrm{kg}$ of $\mathrm{BW}$ gain $/ \mathrm{kg}$ of $\mathrm{CP}$ intake) and total starter intake over the experimental period. Some authors have suggested that higher milk rations can impair rumen development and the digestibility of the starter (Hill et al., 2016), but the results of the present study showed that solid feed intake increased rapidly after weaning in all treatments, and that with appropriate weaning management, the $\mathrm{BW}$ advantage in calves fed more milk was not lost after weaning. Previous studies have found that calves fed more milk had lower ADG during weaning, probably due to low starter intake preweaning (Jasper and Weary, 2002; Cowles et al., 2006), but in the present study, calves from all milk allowances were able to maintain ADG above $0.8 \mathrm{~kg}$ throughout the weaning period. The present study did not measure carcass weight, gut fill, or gut tissue growth, and we encourage future studies to include these measures in calves fed higher allowances of milk in combination with a gradual weaning program.

In the present study, the calves fed higher allowances of milk were able to maintain their weight advantage during and after weaning, perhaps because several techniques were used to encourage solid feeding as described above. One earlier study provided access to forage and grouped calves but did not use step-down weaning (Huuskonen and Khalili, 2008) and found that calves fed high rations of milk were unable to maintain their weight advantage after weaning; this result suggests that gradual weaning may be especially important. The importance of interactions between housing and management factors was illustrated by Jensen et al. (2015), who found that social housing increased starter intake in calves fed higher milk allowances, but not in calves fed a restricted diet. Other work has shown considerable variation in the onset of solid feed intake in calves, reflecting differences in capacity to digest solid feed (Roth et al., 2009). Calves may benefit from weaning protocols tailored to meet the needs of different individuals (de Passillé and Rushen, 2016). More experimental work is needed to compare weaning protocols and identify which features are required and how these interact.

\section{CONCLUSIONS}

Feeding more milk resulted in higher weight gains before weaning, and this weight advantage persisted after weaning. Calves fed less milk showed more unrewarded visits before and during weaning, suggesting that low milk rations leave calves hungry. Calves did not consume their entire milk allowance, a finding that deserves further research.

\section{ACKNOWLEDGMENTS}

We are grateful for the students and staff at the University of British Columbia Dairy Education and Research Centre, especially Gabriella Marquette for her help with data collection. This research was funded via the Natural Sciences and Engineering Research Council's Industrial Research Chair program, with in- 
dustry contributions from the Dairy Farmers of Canada (Ottawa, ON, Canada), the British Columbia Dairy Association (Burnaby, BC Canada), the Westgen Endowment Fund (Milner, BC, Canada), Intervet Canada Corporation (Kirkland, QC, Canada), Novus International Inc. (Oakville, ON, Canada), Zoetis (Kirkland, QC, Canada), the BC Cattle Industry Development Fund (Kamloops, BC, Canada), Alberta Milk (Edmonton, AB, Canada), Valacta (St. Anne-de-Bellevue, QC, Canada), and CanWest DHI (Guelph, ON, Canada).

\section{REFERENCES}

AOAC International. 2000. Official Methods of Analysis. Vol. 1. 17th ed. AOAC Int., Arlington, VA.

Appleby, M. C., D. M. Weary, and B. Chua. 2001. Performance and feeding behavior of calves on ad libitum milk from artificial teats. Appl. Anim. Behav. Sci. 74:191-201.

Bach, A., M. Terré, and A. Pinto. 2013. Performance and health responses of dairy calves offered different milk replacer allowances. J. Dairy Sci. 96:7790-7797.

Borderas, T. F., A. M. B. de Passillé, and J. Rushen. 2009. Feeding behavior of calves fed small or large amounts of milk. J. Dairy Sci. 92:2843-2852.

Costa, J. H. C., R. R. Daros, M. A. G. von Keyserlingk, and D. M. Weary. 2014. Complex social housing reduces food neophobia in dairy calves. J. Dairy Sci. 97:7804-7810.

Costa, J. H. C., R. K. Meagher, M. A. G. von Keyserlingk, and D. M. Weary. 2015. Early pair housing increases solid feed intake and weight gains in dairy calves. J. Dairy Sci. 98:6381-6386.

Costa, J. H. C., M. A. G. von Keyserlingk, and D. M. Weary. 2016. Invited review: Effects of group housing of dairy calves on behavior, cognition, performance, and health. J. Dairy Sci. 99:2453-2467. https://doi.org/10.3168/jds.2015-10144.

Cowles, K. E., R. A. White, N. L. Whitehouse, and P. S. Erickson. 2006. Growth characteristics of calves fed an intensified milk replacer regimen with additional lactoferrin. J. Dairy Sci. 89:48354845.

Dance, A., J. Thundathil, R. Wilde, P. Blondin, and J. Kastelic. 2015. Enhanced early-life nutrition promotes hormone production and reproductive development in Holstein bulls. J. Dairy Sci. 98:987998.

Davis Rincker, L. E., M. J. VandeHaar, C. A. Wolf, J. S. Liesman, L. T. Chapin, and M. S. Weber Nielsen. 2011. Effect of intensified feeding of heifer calves on growth, pubertal age, calving age, milk yield, and economics. J. Dairy Sci. 94:3554-3567.

de Passillé, A. M., T. F. Borderas, and J. Rushen. 2011. Weaning age of calves fed a high milk allowance by automated feeders: Effects on feed, water, and energy intake, behavioral signs of hunger, and weight gains. J. Dairy Sci. 94:1401-1408.

de Passillé, A. M., and J. Rushen. 2016. Using automated feeders to wean calves fed large amounts of milk according to their ability to eat solid feed. J. Dairy Sci. 99:3578-3583. https://doi.org/10.3168/ jds.2015-10259.

de Passillé, A. M. B., and J. Rushen. 2006. Calves' behaviour during nursing is affected by feeding motivation and milk availability. Appl. Anim. Behav. Sci. 101:264-275.

de Paula Vieira, A., A. M. de Passilé, and D. M. Weary. 2012. Effects of the early social environment on the behavioural responses of dairy calves to novel events. J. Dairy Sci. 95:5149-5155.

de Paula Vieira, A., V. Guesdon, A. M. de Passillé, M. A. G. von Keyserlingk, and D. M. Weary. 2008. Behavioral indicators of hunger in dairy calves. Appl. Anim. Behav. Sci. 109:180-189.

de Paula Vieira, A., M. A. G. von Keyserlingk, and D. M. Weary. 2010. Effects of pair versus single housing on performance and behavior of dairy calves before and after weaning from milk. J. Dairy Sci. 93:3079-3085.
Diaz, M. C., M. E. Van Amburgh, J. M. Smith, J. M. Kelsey, and E. L. Hutten. 2001. Composition of growth of Holstein calves fed milk replacer from birth to 105-kilogram body weight. J. Dairy Sci. 84:830-842.

Hepola, H. 2003. Milk feeding systems for dairy calves in groups: effects on feed intake, growth and health. Appl. Anim. Behav. Sci. $80: 233-243$

Hepola, H. P., L. T. Hänninen, S. M. Raussi, P. A. Pursiainen, A.-M. Aarnikoivu, and H. S. Saloniemi. 2008. Effects of providing water from a bucket or a nipple on the performance and behavior of calves fed ad libitum volumes of acidified milk replacer. J. Dairy Sci. 91:1486-1496.

Hill, T. M., H. G. Bateman, J. M. Aldrich, and R. L. Schlotterbeck. 2010. Effect of milk replacer program on digestion of nutrients in dairy calves. J. Dairy Sci. 93:1105-1115.

Hill, T. M., H. G. I. I. Bateman, J. M. Aldrich, J. D. Quigley, and R. L. Schlotterbeck. 2013. Evaluation of ad libitum acidified milk replacer programs for dairy calves. J. Dairy Sci. 96:3153-3162.

Hill, T. M., J. D. Quigley, F. X. Suarez-Mena, H. G. Bateman II, and R. L. Schlotterbeck. 2016. Effect of milk replacer feeding rate and functional fatty acids on dairy calf performance and digestion of nutrients. J. Dairy Sci. 99:6352-6361.

Hötzel, M. J., C. Longo, L. F. Balcão, C. S. Cardoso, and J. H. C. Costa. 2014. A survey of management practices that influence performance and welfare of dairy calves reared in southern Brazil. PLoS One 9:e114995.

Huuskonen, A., and H. Khalili. 2008. Computer-controlled milk replacer feeding strategies for group-reared dairy calves. Livest. Sci. 113:302-306.

Jasper, J., and D. M. Weary. 2002. Effects of ad libitum milk intake on dairy calves. J. Dairy Sci. 85:3054-3058.

Jensen, M. B. 2006. Computer-controlled milk feeding of group-housed calves: The effect of milk allowance and weaning type. J. Dairy Sci. 89:201-206.

Jensen, M. B., L. R. Duve, and D. M. Weary. 2015. Pair housing and enhanced milk allowance increase play behavior and improve performance in dairy calves. J. Dairy Sci. 98:2568-2575.

Jensen, M. B., and L. Holm. 2003. The effect of milk flow rate and milk allowance on feeding related behavior in dairy calves fed by computer-controlled milk feeders. Appl. Anim. Behav. Sci. 82:87100.

Khan, M. A., A. Bach, D. M. Weary, and M. A. G. von Keyserlingk. 2016. Invited review: Transitioning from milk to solid feed in dairy heifers. J. Dairy Sci. 99:885-902.

Khan, M. A., H. J. Lee, W. S. Lee, H. S. Kim, S. B. Kim, K. S. Ki, J. K. Ha, H. G. Lee, and Y. J. Choi. 2007. Pre- and postweaning performance of Holstein female calves fed milk through step-down and conventional methods. J. Dairy Sci. 90:876-885.

Khan, M. A., D. M. Weary, and M. A. G. von Keyserlingk. 2011a. Invited review: Effects of milk ration on solid feed intake, weaning, and performance in dairy heifers. J. Dairy Sci. 94:1071-1081.

Khan, M. A., D. M. Weary, and M. A. G. von Keyserlingk. 2011b. Hay intake improves performance and rumen development of calves fed higher quantities of milk. J. Dairy Sci. 94:3547-3553.

Kiezebrink, D. J., A. M. Edwards, T. C. Wright, J. P. Cant, and V. R. Osborne. 2015. Effect of enhanced whole-milk feeding in calves on subsequent first-lactation performance. J. Dairy Sci. 98:349-356.

Kristensen, N. B., J. Sehested, S. K. Jensen, and M. Vestergaard. 2007. Effect of milk allowance on concentrate intake, ruminal environment, and ruminal development in milk-fed Holstein calves. J. Dairy Sci. 90:4346-4355.

Miller-Cushon, E. K., R. Bergeron, K. E. Leslie, and T. J. DeVries. 2013. Effect of milk feeding level on development of feeding behavior in dairy calves. J. Dairy Sci. 96:551-564.

Nielsen, P. P., M. B. Jensen, and L. Lidfors. 2008. Milk allowance and weaning method affect the use of a computer controlled milk feeder and the development of cross-sucking in dairy calves. Appl. Anim. Behav. Sci. 109:223-237.

NRC. 2001. Nutrient Requirements of Dairy Cattle. 7th rev. ed. Natl. Acad. Press, Washington, DC. 
Raeth-Knight, M., H. Chester-Jones, S. Hayes, J. Linn, R. Larson, D. Ziegler, B. Ziegler, and N. Broadwater. 2009. Impact of conventional or intensive milk replacer programs on Holstein heifer performance through six months of age and during first lactation. J. Dairy Sci. 92:799-809.

Roth, B. A., N. M. Keil, L. Gygax, and E. Hillmann. 2009. Influence of weaning method on health status and rumen development in dairy calves. J. Dairy Sci. 92:645-656.

Soberon, F., E. Raffrenato, R. W. Everett, and M. E. Van Amburgh. 2012. Preweaning milk replacer intake and effects on long-term productivity of dairy calves. J. Dairy Sci. 95:783-793.

Soberon, F., and M. E. Van Amburgh. 2013. Lactation Biology Symposium: The effect of nutrient intake from milk or milk replacer of preweaned dairy calves on lactation milk yield as adults: A metaanalysis of current data. J. Anim. Sci. 91:706-712.

Staněk, S., V. Zink, O. Dolezal, and L. Stolc. 2014. Survey of preweaning dairy calf-rearing practices in Czech dairy herds. J. Dairy Sci. 97:3973-3981.

Sweeney, B. C., J. Rushen, D. M. Weary, and A. M. de Passillé. 2010. Duration of weaning, starter intake, and weight gain of dairy calves fed large amounts of milk. J. Dairy Sci. 93:148-152.

Terré, M., M. Devant, and A. Bach. 2007. Effect of level of milk replacer fed to Holstein calves on performance during the preweaning period and starter digestibility at weaning. Livest. Sci. 110:82-88.
Thomas, T. J., D. M. Weary, and M. C. Appleby. 2001. Newborn and 5 -week old calves vocalize in response to milk deprivation. Appl. Anim. Behav. Sci. 74:165-173.

USDA. 2016. Dairy 2014: Dairy Cattle Management Practices in the United States, 2014. NAHMS \#692.0216. USDA-Animal and Plant Health Inspection Service (APHIS)-Veterinary Services (VS)-Center for Epidemiology and Health (CEAH), Fort Collins, CO.

Van Soest, P. J., J. B. Robertson, and B. A. Lewis. 1991. Methods for dietary fiber, neutral detergent fiber and non-starch polysaccharides in relation to animal nutrition. J. Dairy Sci. 74:3583-3597.

Vasseur, E., D. Pellerin, A. M. de Passillé, C. Winckler, B. J. Lensink, U. Knierim, and J. Rushen. 2012. Assessing the welfare of dairy calves: Outcome-based measures of calf health versus input-based measures of the use of risky management practices. Anim. Welf. 21:77-86.

Weary, D. M., J. Jasper, and M. J. Hötzel. 2008. Understanding weaning distress. Appl. Anim. Behav. Sci. 110:24-41.

Yavuz, E., N. Todorov, G. Ganchev, and K. Nedelkov. 2015. The effect of feeding different milk programs on dairy calf growth, health and development. Bulg. J. Agric. Sci. 21:384-393. 